\title{
Influence of two management systems on the growth performance of adult African giant land snails (Archachatina marginata)
}

\section{Z. Dododawa*}

Department of Forest Resources and Wildlife Management, University of Benin, Benin City, Nigeria

\section{B. N. Ejidike}

Department of Ecotourism and Wildlife Management, Federal University of Technology, Akure, Nigeria

${ }^{*}$ Corresponding author. E-mail: zubeiru.dododawa@uniben.edu

\begin{abstract}
African gaint land snails are important as means of alleviating acute protein shortage in Nigeria livestock Industries. The present study aimed to study the influence of intensive and extensive management systems on the growth Performance of adult African Giant Land Snails (Archachatina marginata) was carried out in the wildlife domestication unit of the Department of Forest Resources and Wildlife Management, University of Benin, Benin City, Nigeria. Ninety African giant land snails (A. marginata) of average body weight $160.31 \mathrm{~g} \pm 0.38 \mathrm{~g}$ were used for the study. The snails were grouped into two- Group $A$ and Group B. 45 snails in group A were raised in an intensive system of management while 45 snails in group B were raised in an extensive system of management. The data collected on weight gain, shell length increment and shell width increment during the experiment were subjected to student $\mathrm{t}-$ Test at $5 \%$ significant level. Results showed that there was a significant difference at $(p<0.05)$ in the weight gain. The intensive management system had a higher weight gain of $128.96 \mathrm{~g}$ with mean value of 4.96 while the extensive management system had a weight gain of $88.37 \mathrm{~g}$ with mean value of 3.40 . There was no significant difference at $(p>0.05)$ in the shell length increment. The snails in the extensive management system had the higher shell length increment of $5.32 \mathrm{~cm}$ with mean value of 0.20 while the snails in the intensive management system had a shell length increment of $2.43 \mathrm{~cm}$ with mean value of 0.09 . There was a significant difference at $(p<0.05)$ in the shell width increment. The snails in the extensive management system had the higher shell width increment of $9.31 \mathrm{~cm}$ with mean value of 0.36 while the snails in the intensive management system had a shell width increment of $4.30 \mathrm{~cm}$ with mean value of 0.17 . The snails in the intensive system had a Feed Conversion Ratio of 5.03. For better growth performance of $A$. marginata in terms of weight gain, snail farmers should raise their snails in an intensive system of management and formulated diet should be used in feeding the snails along side with natural feed such as leaves and fruits.
\end{abstract}

Keywords: African giant land snails, Feed Conversion Ratio, Shell length increment, Weight gain

\section{INTRODUCTION}

Snails are bilaterally symmetrical invertebrates with soft segmented exoskeleton in the form of calcerous shells and belong to the phylum mollusca. In west Africa, snails dwell in humid forest areas from where they are gathered for consumption and other uses (Ademosu and Omidiji, 1999). Snails are invertebrate shell bearing animal that are passive or inactive during the day but very active in the night, at dusk or when it rains. They are usually found in cool environment (Amusan and Omidiji, 1999; Omole, 2001). Snails are the largest group of molluscs constituting the largest animal group next to arthropods. They have high

\section{Article Info}

DOI:10.31018/jans.v11i2.2073

Received: April 10, 2019

Revised: May 22, 2019

Accepted: May 29, 2019

\section{How to Cite}

Dododawa, Z. and Ejidike, B.N. (2019). Influence of two management systems on the growth performance of adult African giant land snails (Archachatina marginata). Journal of Applied and Natural Science, 11 (2): 424 - 428 https://doi.org/10.31018/ jans.v11i2.2073 
courage the eating of snail meat or the eating of certain species of snails to the detriment of others. Uboh et al. (2010) observed Archachatina marginata to be generally accepted for consumption, and strong cultural discrimination in the consumption of Achatina achatina by some tribes in Southern Nigeria. Studies by Omole et al., (2000) have shown that different breeds of snails can be found in Nigeria and they are characterized by high efficiency of nutrient transformation into quality protein. The African giant land snail ( $A$. marginata) is the largest known snail in Africa (Omole, 1998; Olawoyin and Ogogo, 2006) and dwells naturally in the forest litters of the tropical rainforest zone of Nigeria (Adedire et al., 1999). Omole (1998) stated that the African giant snail (A. marginata) is the most common edible land snail found and reared in Nigeria. A short supply of wild population of snail is on the increase due to decline in snail population resulting from human impacts and other anthropogenic factors such as deforestation, slash and burn agricultural practices and over exploitation of these animals (Eneji, Ogogo, Emmanuel-Ikpeme and Okon, 2008; Raut and Barker, 2002). It has been reported that snail's availability is seasonal (Ugwu, Ogbu and Ikechiuno, 2011), being much more available in the rainy season and scarce during the dry season (Oshiyemi, 2011), because they aestivate during the dry season (Okafor, 2001). The primary task of addressing the malnutrition problems through increased animal protein intake requires production of protein from animal sources in the right quantity and quality. The contribution made by domestic animals (conventional sources) as protein supply are not enough, there is therefore need to look at some unconventional sources (Etchu, et al., 2008). To achieve this, there is need to encourage the raising of some wildlife species such as snail and cane rat. Snails have become a tool for poverty alleviation (Ebenso, 2006) and it has been discovered that snail production is associated with rapid returns per unit investment (Adinya, 2006). The objectives of the study was to determine the growth performance of African giant land snail ( $A$. marginata) in terms of weight gain, shell length increment, shell width increment, feed intake and feed conversion ratio.

\section{MATERIALS AND METHODS}

Study area: The experiment was carried out in the Wildlife domestication unit of the Department of Forestry and Wildlife, University of Benin, Benin City, Nigeria. The Ugbowo main campus of the University of Benin has a total land area of 1,748 hectares. It is located between latitude $6.1^{0} \mathrm{~N}$ and $6.8^{0} \mathrm{~N}$ of the equator and longitude $5.4^{\circ} \mathrm{E}$ and $6.0^{\circ} \mathrm{E}$ of the Greenwich meridian. The altitude is $74.5 \mathrm{~m}$ above sea level.

Experimental snails: Ninety African giant land snails ( $A$. marginata) of average body weight $160.31 \mathrm{~g} \pm 0.38 \mathrm{~g}$ were used for the study. The snails were grouped into two- Group A and Group B. 45 snails in group $A$ were raised in an intensive system of management while 45 snails in group $B$ were raised in an extensive system of management. The intensive system of management is a system of management where the animals (snails) are confined in an enclosure and restricted from moving freely, feed and water are provided to the animals on a daily basis, the eggs and the young ones are well taken care of and the enclosure checked regularly to ensure that the animals are comfortable. The extensive system of management is a system of management where the animals (snails) are allowed to move freely in a large expanse of land, they feed on the plants and other sources of food in the environment, rely on water from rainfall, the eggs are left to hatch naturally and the young ones are left to grow with the adult ones.

Housing: Wooden cage of dimension $4.5 \mathrm{~m} \times$ $0.6 \mathrm{~m} \times 0.5 \mathrm{~m}$ (Ejidike, 2001) was constructed and used to house the snails in group $A$. The cage was divided into 3 parts with each part of dimension $1.5 \mathrm{~m} \times 0.6 \mathrm{~m} \times 0.5 \mathrm{~m}$. The cage stood $40 \mathrm{~cm}$ off the ground. 45 snails in group A were grouped into 15 snails per replicate (replicate I-III) and stocked randomly in each part of the cage. The cage was filled with loamy soil up to $18 \mathrm{~cm}$ thickness. The other 45 snails in group $B$ were housed in an extensive system of management. The snails were placed in a free-range pen. An area of $9 \mathrm{~m} \times 3 \mathrm{~m} \times 2 \mathrm{~m}$ was established, snail plant food materials and shelter plants were planted within the enclosure. The snails were allowed to move over the entire area-free range. The area was divided into 3 parts (three replicates) each of dimension $3 \mathrm{~m} \times 3 \mathrm{~m} \times 2 \mathrm{~m}$. Fifteen snails were stocked in each of the part.

Experimental design and treatment: A Completely Randomize Design (CRD) was used in the experiment. The ninety (90) snails were randomly distributed to 2 treatments - the intensive management system and extensive management system. Each of the treatment was replicated 3 times, with 15 snails per replicate and 45 snails per treatment.

Feeding and watering: Feed were supplied to the snails in the intensive management system at 1800 hours. Feeding was done in the evening and the left over feed in the subsequent evening was weighed. This was to ensure that their food is always fresh at the time of feeding as snails are nocturnal animals. The weight was subtracted from the initial weight of the feed supplied to estimate the feed intake. The Feed Conversion Ratio was calculated as the ratio of feed intake to weight gain. Formulated feed of $25 \%$ crude protein was also used to feed the snails. Natural feeds like 
fruits of pawpaw, watermelon, pineapple and leaves of pawpaw and cocoyam were used to feed the snails. The natural and formulated feed were given to the snails at alternate days. Water was provided to the snails by making the soil moist as snails have the ability to obtain water from moist soil. Regular cleaning of the snailery and utensils as well as routine management practices were ensured. The snails in the extensive management system were allowed to feed naturally on the plant materials planted within the enclosure. Pawpaw and cocoyam plants were planted within the enclosure to serve as source of food and shelter for the snails.

Data collection: Data were collected on the weight gain, shell length increment, shell width increment, feed intake and Feed Conversion Ratio for a period of 52 weeks. The snails were marked with a permanent marker for easy identification. The weight gain, shell length increment and shell width increment of the snails were measured once every two weeks. The weight of the snails were measured using an electronic weighing balance, the shell length was measured by using a measuring tape from the tip of the shell to the base and measured to the nearest centimeter, the shell width was measured by using a thread to measure the broad circumference of the shell and the values were read off on a ruler to the nearest centimeter.

Statistical analysis: The data collected on weight gain, shell length increment and shell width increment during the experiment were subjected to student $t-T e s t$ at $5 \%$ significant level.

\section{RESULTS}

Snail weight gain: The result of the snail weight gain revealed that there was a significant difference at $(p<0.05)$ in the weight gain of the two management systems. The intensive management system had the higher weight gain of $128.96 \mathrm{~g}$ with mean value of 4.96 while the extensive management system had a weight gain of $88.37 \mathrm{~g}$ with mean value of 3.40 (Table 3 ).

Snail shell length increment: The result of the snail shell length increment revealed that there was no significant difference at $(p>0.05)$ in the shell length increment of the two management systems. The snails in the extensive management

Table 1. Percentage composition of the formulated feed with $25 \%$ crude protein.

\begin{tabular}{ll}
\hline Ingredients & Percentage (\%) composition \\
\hline Maize & 50.00 \\
Soyabean meal & 15.00 \\
Groundnut cake & 15.00 \\
Fishmeal & 5.00 \\
Bonemeal & 10.00 \\
Vitamin premix & 2.50 \\
Limestone & 2.50 \\
Total & $\mathbf{1 0 0}$ \\
\hline \hline
\end{tabular}

system had the higher shell length increment of $5.32 \mathrm{~cm}$ with mean value of 0.20 while the snails in the intensive management system had a shell length increment of $2.43 \mathrm{~cm}$ with mean value of 0.09 (Table 4).

Snail shell width increment: The result of the snail shell width increment revealed that there was a significant difference at $(p<0.05)$ in the shell width increment of the two management systems. The snails in the extensive management system had the higher shell width increment of $9.31 \mathrm{~cm}$ with mean value of 0.36 while the snails in the intensive management system had a shell width increment of $4.30 \mathrm{~cm}$ with mean value of 0.17 (Table 5).

Snail feed conversion ratio (FCR): The result of the Snail Feed Intake and the Feed Conversion Ratio (FCR) in the intensive system is represented in Table 6.

\section{DISCUSSION}

The growth performance of $A$. marginata in the intensive and extensive management systems were measured by the weight gain, shell length increment and shell width increment. The snails in the intensive management system had a higher weight gain than the snails in the extensive management system. This could be as a result of the formulated feed of $25 \%$ crude protein in addition to the natural feed used in feeding the snails. This agrees with the findings of Omole (2002) that weight gain of snail is directly proportional to the level of protein in the diet. This is also in agreement with Akintomide (2004), that African land giant snails like other farm animals prefer to be fed on a combination of feeds rather than just feeding on a particular type of food. The higher weight gain of snails in the intensive management system could be as a result of the high crude protein in the diet. This finding is also in agreement with Adeyemo and Borire (2000) that reported significant differences in the body weight gain of snails fed different levels of yam peel. The snails in the extensive management system had higher shell length and shell width increment than the snails in the intensive management system. The increase in shell length and shell width occurred throughout the year even in the dry season. This is an indication that snails grow in shell size even during the

Table 2. Proximate composition of feed.

\begin{tabular}{ll}
\hline Composition & Percentage (\%) \\
\hline Ash & 8.25 \\
Dry matter & 90.73 \\
Lipid & 3.14 \\
Crude fibre & 3.27 \\
Moisture content & 9.27 \\
Crude protein & 24.50 \\
Nitrogen Free Extract (NFE) & 51.57 \\
\hline Source: Laboratory Analysis, 2018
\end{tabular}


Dododawa, Z. and Ejidike, B.N. / J. Appl. \& Nat. Sci. 11(2): 424 - 428 (2019)

Table 3. Archachatina marginata mean weight gain (g).

\begin{tabular}{lll}
\hline & Intensive system & Extensive system \\
\hline Initial body weight & $160.31 \pm 0.38$ & $160.31 \pm 0.38$ \\
Final body weight & 289.27 & 248.68 \\
Total Weight gain & 128.96 & 88.37 \\
Mean weight gain & $\mathbf{4 . 9 6} \mathbf{b}^{\mathrm{a}} \pm \mathbf{1 . 0 2}$ & $\mathbf{3 . 4 0 ^ { \mathrm { b } } \pm \mathbf { 0 . 9 4 }}$ \\
\hline
\end{tabular}

Means with different superscript indicated that they are significantly different at $(p<0.05)$

Table 4. Archachatina marginata mean Shell length increment $(\mathrm{cm})$.

\begin{tabular}{|c|c|c|}
\hline 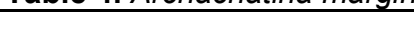 & Intensive system & Extensive system \\
\hline Initial shell length & $9.98 \pm 0.15$ & $9.98 \pm 0.15$ \\
\hline Final shell length & 12.41 & 15.30 \\
\hline Total shell length increment & 2.43 & 5.32 \\
\hline Mean shell length increment & $0.09^{a} \pm 0.01$ & $0.20^{a} \pm 0.01$ \\
\hline
\end{tabular}

Means with the same superscript indicated that they are not significantly different at $(p>0.05)$

Table 5. Archachatina marginata mean Shell width increment $(\mathrm{cm})$.

\begin{tabular}{|c|c|c|}
\hline & Intensive system & Extensive system \\
\hline Initial shell width & $17.12 \pm 0.30$ & $17.12 \pm 0.30$ \\
\hline Final shell width & 21.42 & 26.43 \\
\hline Total shell width increment & 4.30 & 9.31 \\
\hline Mean shell width increment & $0.17^{\mathrm{a}} \pm 0.02$ & $0.36^{b} \pm 0.02$ \\
\hline
\end{tabular}

Means with different superscript indicated that they are significantly different at $(p<0.05)$

Table 6. Archachatina marginata Feed Conversion Ratio (FCR).

\begin{tabular}{ll}
\hline & Intensive System \\
\hline Total Feed Intake (g) & 648.74 \\
Total Weight Gain (g) & 128.96 \\
Feed Conversion Ratio (FCR) & 5.03 \\
\hline${ }^{1}$ FCR = Total Feed Intake/ Total Weight Gain \\
dry season, though the growth rate was reduced. \\
The higher shell length and shell width increment \\
of the snails in the extensive management system \\
could be due to the spacious environment in \\
which the snails in the extensive management \\
system were exposed to. Snails grow well when \\
the environment is spacious and have free access \\
to their feed. This is in line with the findings of \\
Ayodele and Asimalowo (1999) that the perfor- \\
mance of snails are affected by space and num- \\
ber. The high Feed Conversion Ratio (FCR) of $A$. \\
marginata (5.03) is in line with Badmos et al. \\
(2011) who reported FCR range of 1.40 to 1.61 for \\
growing $A$. marginata, while Ademolu et al. (2014) \\
reported FCR range of 1.33 to 4.84 for one month \\
old $A$. marginata. The high feed conversion ratio \\
of $A$. marginata is an indication that $A$. marginata \\
did not utilize the nutrients available in the $25 \%$ \\
crude protein diets efficiently.
\end{tabular}

\section{Conclusion}

From these results, it could be deduced that the formulated feed of $25 \%$ crude protein used in feeding the $A$. marginata in the intensive system of management contributed to the higher weight gain while the snails in the extensive system of management had a higher shell length and shell width increment probably because of the large space they were exposed to. The feed conversion ratio of $A$. marginata was high indicating that the A. marginata did not utilize and convert the feed to body tissues efficiently. For better growth performance of $A$. marginata in terms of weight gain, snail farmers should raise their snails in an intensive system of management and formulated diet should be used in feeding the snails along side with natural feed such as leaves and fruits.

\section{REFERENCES}

1. Adedire, C. O., Imevbore, E. A., Eyide, E. O. and Ayodele, W. I. (1999). Aspects of physiology and complementary roles of the microbial enzymes in the intestinal tract of giant land snail (Archachatina marginata) (Swainson). Journal of Technoscience, 3, 611.

2. Ademolu, K.O., Idowu, A. B., Mafiang, C. F. and Osinowo, O. A. (2014). Performance, Proximate and mineral analysis of African Giant Land Snails (Archachatina marginata) fed different nitrogen sources. African Journal of Biotechnology 3(8): 412417.

3. Ademosu, A. A., Omidiji, M. O. (1999). The nutrient value of African giant land snail (Archachatina marginata). Journal of Animal Protection Research 8(2): 876-877.

4. Adeyemo, A. I. and Borire, O. F. (2000). Response of African Giant Land Snails fed Graded levels of yam peel meal. Proc. Of $27^{\text {th }}$ Conference of Nigeria Society for Animal Production (NSAP), Federal University of Technology, Akure, Nigeria. Pp 45

5. Adinya, I. B. (2006). Snail Production: Extension Bulletin Guide, 1(1) 1-3.

6. Akinnusi, O. (2004). Introduction to snails and snail farming. $2^{\text {nd }}$ ed. Abeokuta, Nigeria. Triolas Exquisite Ventures.

7. Akinnusi, F.A.O., Bamgbose, A.M., Odunaro, O.E., Alade, A.A. (2007): Comparative effect of different animal protein concentrates on Carcass quality of Rabbits. Paper presented at Annual Conference of 
the Nigeria Society for Animal Production. Calabar.

8. Akintomide, O. (2004). Tropical Snail farming. Ibadan: Oakman Ventures.

9. Amusan, J.A. and Omidiji, M.O. (1999): Edible Land Snail: A Technical guide to Snail Farming in the Tropics. Ibadan: Varity Printers Limited.

10.Ayodele, I. A. Asimalowo, A. A. (1999). Essentials of Snail Farming. Agape Printers, Ibadan. Pp 7-37.

11.Badmos, A.H.A., Joseph, J.K., Belewu, M.A. and Okukpe, K. M. (2011). Growth parameters of Giant African Land Snails as influenced by different sources of dietary calcium. Proceedings of the $36^{\text {th }}$ Conference of Nigerian Society of Animal Production. 13- 16 March, 2011, University of Abuja.

12.Ebenso, I. E. (2006). A note on the effect of water on incubating eggs of edible tropical land snail. Limicolaria aurora. Livestock research for rural development 18 (10) 2006.

13.Ejidike, B. N. (2001). Dietary protein requirements of the African giant land snails (Archachatina marginata). Applied Tropical Agriculture. 6: 111-115

14.Eneji, C. A., Ogogo, A. U., Emmanuel-Ikpeme, C. A. and Okon, O. E. (2008). Nutritional Assessment of some Nigerian Land and Water Snail Species. Ethiopian Journal of Environmental Studies and Management, 1 (2): 56-60.

15.Etchu, K., Mafeni, M. and Ngenwi, A. (2008): Comparative performance of three edible snail species using intensive cage housing system in Cameroon. Bull. Anim. Health Prod. Afr. 56: 345-352.

16.Malik, A.A. and Dikko, A.H. (2009). Heliculture in Nigeria: The Potentialities, Opportunities and Challenges. (A Review). Proceedings of the $34^{\text {th }}$ Annual conference of Nigerian Society for Animal production, University of Uyo Town Campus, pp. 120-124

17. Okafor, F. U. (2001). Edible land snails: a manual of biological management and farming of snails. Splendid Publishers, Badagry, Lagos, Nigeria.

18. Olawoyin, O. O. and Ogogo, A. U. (2006): Prediction of Optimum Stocking Density in growing African Giant Land Snails. Tropical Journal of Animal Science, 9(2), 75-84.
19.Omole, A. J. (1998). The utilization of different energy supplements on performance characteristics of grower Edible giant land snail (Archachatina marginata). Master of Science Thesis. Animal Science Department, University of Ibadan, Ibadan, Nigeria.

20. Omole, A. J, Tewe, O.O. Adebowale, E.A, Oluokun J.A and Nworgu, F.C. (2000). Performance of different breeds of snails under the same management conditions. Tropical Journal of Animal Science 3(1). Pp. 133-138.

21.Omole A. J. (2001). How to start and manage Snail Farming. A paper presented at workshop organized by Petroleum Staff Training Programme for Retiree at Petroleum Training Institute Effunrun Warri, Delta State on March 13-15th 2001

22.Omole, A. J. (2002): Nutrient requirements for different stages of growth of African Giant Land Snails. Ph.D Thesis, Animal Science Department, University of Ibadan, Nigeria.

23.Omole, A.J., Taiwo, A.A. and Amusan, J.A. (2007). Technical Guide/Bulletin. Practical Snail Farming. Obafemi Awolowo University, More Plantation, Ibadan, Nigeria: Bora Agro Ventures.

24.Oshiyemi, O. M. (2011). Effect of level of humidity on productive and reproductive parameters of Giant African Land Snail. B.Agric Thesis, University Of Agriculture, Abeokuta, Nigeria.

25.Raut, S. K. and Barker, G. M. (2002). Achatina fulica Bowdish and other Achatinidae as pests in tropical agriculture. In Barker G. M. (ed). Molluscs as crop pests. CAB Int.: 55-114.

26.Uboh, F.E., Ebong, P. E., Mbi, E. (2010). Cultural discrimination in the Consumption of black snail (Archatina marginata) and white snail (Achatina achatina); any scientific justification? International Research Journal of Microbiology. 2010; 1(1): 013017.

27.Ugwu S. O. C., Ogbu C. C. and Ikechiuno I. K. (2011). Reproductive characterization of three species of Giant African land snails (GALs) in captivity. African Journal of Biotechnology, 10(50), 1031510319. 